\title{
DETECTING THE SUITABLE IRRIGATION SYSTEMS AND CROPS BY APPLICATION OF GEOGRAPHIC INFORMATION SYSTEMS (GIS)
}

Waleed Mohammed Bassiuony Darwisch*

\author{
ABSTRACT
}

The main objective of this work is to detect the suitable irrigation systems and crops based upon soil properties in new farm as a reclaimed area at Wadi El-Natroun. Studied area which extends about 634 feddans were surveyed by digging 454 soil profiles representing current farms and dominant problems. The soil properties of the study area such as texture, depth, electrical conductivity, soil reaction $(\mathrm{pH})$, calcium carbonate content, sodium adsorption Ratio (SAR), elevation, and slope. Once the soil properties were analyzed and evaluated, suitability maps were generated for the studied area using geographic information system. The soils of the studied area are nonsaline to moderately saline (EC values range from 1.0 to $>16 \mathrm{dS} / \mathrm{m})$. Soil texture is mostly sandy to sandy loam \{(clay percentage (4.5: $8.7 \%)$, silt percentage (4.3: $22.1 \%)$, and sand percentage (69.2: 91.2\%)\}. Soil $\mathrm{pH}$ values range from 2 to 8.0, Sodium Adsorption Ratio (SAR) range from $0.5 \%$ to $>16 \%$ and slope range from $1 \%$ to $15 \%$. The obtained results indicated that, $85.5 \%$ of the studied area were suitable for cultivation and $14.5 \%$ of the studied area were unsuitable for cultivation according to EC and (SAR), $28.12 \%$ of suitable area were optimal for surface irrigation system and $71.88 \%$ of suitable area were optimal for sprinkler and drip irrigation systems according to slope. $91.5 \%$ of the studied area were alkaline soil, $8.25 \%$ were neutral soil and $0.25 \%$ were acid soil according to ph. Additionally, Because the water used in irrigation is groundwater, so it's best to use the sprinkler and drip irrigation systems instead of surface irrigation system. Moreover, the main limiting factors in using different irrigation systems in this area were (soil texture, $\mathrm{CaCo}_{3}$ and slope) and electrical conductivity (EC) for crops. In conclusion, the using GIS maps reliable to be a good indicator for detecting the suitable irrigation systems and crops for this area of study.

Keywords: Irrigation, soil properties, slope, GIS

*Assistant Prof. of Agric. Eng. Evaluation of Natural Resources Department, Environmental Studies and Research Institute, Sadat City University. 


\section{INTRODUCTION}

$\mathrm{D}$ etecting the suitable irrigation systems and crops by application of Geographic Information Systems (GIS) is a very important piece of information in agriculture development and future planning. Based on that, a land suitability for Agriculture purpose has been conducted in order to help decision makers, agriculture development planners and determine how proper or appropriate it is for a particular use of the land in a particular location which are more suitable for certain agriculture use. There is no doubt that the ratio between the land resources and human resources is the most critical problem in Egypt. So agriculture expansion in the Western Desert is one of the most vital objectives of the Egyptian policy to meet the food security requirements of the tremendous increase in population. Wadi El-Natrun area could be considered as one of the promising areas for agricultural development. Land suitability is essential for the studied area in order to provide the planners with the necessary information they needed. However, sometimes the survey data are difficult to be understood by them. When, the variables are translated into productivity terms, they become more relevant and supporting.

The intensification of agriculture is the most likely means to meet food demand of growing population, the land resources need to be utilized to the fullest extent. Land suitability analysis is a prerequisite for sustainable crop production. Crops grow best in locations where the climatic conditions meet their growth requirements. Elevation, slope, aspect, soil $(\mathrm{pH}$, drainage and texture), land cover and many climatic factors that affect crop growth, help in determining the most suitable crop growth areas. The process of land suitability classification is the evaluation and grouping of specific areas of land in terms of their suitability for a defined use. The main objective of the land evaluation is the prediction of the inherent capacity of a land unit to support a specific land use for a long period of time without deterioration, in order to minimize the socioeconomic and environmental costs (De la Rosa, 2000). The Land Suitability Classification Under a Framework for Land Evaluation developed by FAO (2007), the land suitability is a system to evaluate the 
grouping of soil in term of their suitability for defined uses. Land suitability is divided into two orders: Suitable and Not suitable. The suitable order is divided into three classes. The four classes of land suitability that are recognized that are: Class S1 highly suitable: Land has no significant limitations to reduce productivity. Class S2 Moderately suitable: Land has moderately severe limitations to reduce productivity. Class 3 Marginally suitable: Land has severe limitations to reduce productivity. Class N Not suitable: Land has very severe limitations to produce economic crops. Class S1 and S2 of Land suitability classification are also in a meaning of prime agricultural land. (Stockle, 2007) estimates indicate that about one-third of the irrigated lands in the major countries with irrigated agriculture is badly affected by salinity or is expected to be salinized in the near future. Current estimates of the saltaffected soils as percent of the irrigated lands for different countries are: $27 \%$ for India, 28\% for Pakistan, 13\% for Israel, 20\% for Australia, 15\% for China, 50\% for Iraq, and 30\% for Egypt. Khalifa (2009) studied the assessment of soil limiting factors effect on land productivity at Wadi ElFaregh area, West of Delta, Egypt. This study aimed at evaluating the influence of soil limiting characteristics on its productivity in a newly reclaimed area at Wadi El-Faregh area. He concluded that, limiting properties of land capability may be concluded as dominant sand content, shallow profile depth at some sites, salt and/or lime some affected sites and poor fertility status. The studied area is evaluated as order "Suitable" and classified into two capability classes; "Fair" representing $83.6 \%$ as productivity index ranged between $41.057 .3 \%$, and "Poor" extending over $16.4 \%$ of the area with productivity index varied from $29.535 .9 \%$. Best recommended winter crops are wheat, barely, alfalfa and faba bean, while in summer they are sorghum, sunflower and peanut. Seven different fruit trees are suitable in the studied area with the following sequence: date palm, olive, grape, apple, citrus, pummel and guava. Land evaluation is a process of predicting land performance over time according to the specific types of use (Lee and Yeh, 2009; Martin and Saha, 2009; Sonneveld et al., 2010). Agriculture land suitability assessment is defined as the process of assessment of land performance when used for alternative kinds of agriculture. The principle purpose of agriculture land 
suitability evaluation is to predict the potential and limitation of the land for crop production (Pan and Pan, 2012). Land suitability for agriculture is a very important piece of information in agriculture development and future planning. Based on that, a land suitability assessment for Agriculture purpose has been conducted in order to help decision makers, agriculture development planners and determine how proper or appropriate it is for a particular use of the land in a particular location which are more suitable for certain agriculture use. Its major objective is to find out places which are most suitable for certain agricultural use. Land suitability tools have been extensively applied to identify better management Practices in agricultural areas. These tools evaluate the suitability of an agricultural Land to a specific practice or land use. So, GIS has contributed to the speed and efficiency of overall planning process in agricultural land use suitability because quick and efficient access to large amount of information was enabled by GIS, exhibiting relationships, patterns, and trends that are useful in combining soil survey information to monitor land use suitability evaluation. (Singha and Swain 2016). Good planning is essential for successful irrigation, including: 1) The selection of an irrigation system that provides the best practical and economical irrigation system alternative, 2) the design and installation of a system according to standards and accepted engineering practice and 3) system management that ensures a correct and timely application of water that is based on crop requirements and avoids unnecessary water use (Holzapfel et al., 1985). Sys et al. (1991) suggested a parametric evaluation system for irrigation methods which was primarily based upon physical and chemical soil properties. In their proposed system, the factors affecting soil suitability for irrigation purposes can be subdivided into four groups: Physical properties determining the soil-water relationship in the soil such as permeability and available water content; Chemical properties interfering with the salinity/alkalinity status such as soluble salts and exchangeable $\mathrm{Na}$; Drainage properties; and Environmental factors such as slope. Mbodj et al. (2004) performed a land suitability evaluation for two types of irrigation, i.e., surface irrigation and drip irrigation, in the Tunisian Oued Rmel Catchment using the suggested parametric evaluation. According to 
the results, the drip irrigation suitability gave more irrigable areas compared to the surface irrigation practice due to the topographic slope, soil depth and texture, and drainage limitations encountered within the surface irrigation suitability evaluation. Barberis and Minelli (2005) provided land suitability classification for both surface and drip irrigation methods in Shouyang County, Shanxi Province, China, where the study was carried out by a modified parametric system. The results indicated that due to the unusual morphology, the area suitability for the surface irrigation $34 \%$ is smaller than the surface used for the drip irrigation $62 \%$. The most limiting factors were physical parameters including slope and soil depth. Liu et al. (2006) evaluated the land suitability for surface and drip irrigation in the Danling County, Sichuan Province, China using a Sys's parametric evaluation system. For surface irrigation the most suitable areas S1 represented about 24\% of Danling County, 33\% was moderately suitable S2, \%9 was classified as marginally suitable S3, 7\% of the area was founded currently not suitable $\mathrm{N} 1$ and $25 \%$ was very unsuitable for surface irrigation due to their high slope gradient. Drip irrigation was everywhere more suitable than surface irrigation due to the minor environmental impact that it caused. Areas highly suitable for this practice covered $38 \%$ of Danling County; about $10 \%$ was marginally suitable the steep dip slope and the structural rolling rises of the Jurassic period. The steeper zones of the study area 23\% were either approximately or totally unsuitable for such a practice. Dengize (2006) also compared different irrigation methods including surface and drip irrigation in the pilot fields of central research institute, Lkizce research farm located in southern Ankara. He concluded that the drip irrigation method increased the land suitability by $38 \%$ compared to the surface irrigation method. The most important limiting factors for surface irrigation in study area were soil salinity, drainage, and soil texture, respectively, whereas the major limiting factors for drip or localized irrigation were soil salinity and drainage. Albaji et al. (2008) carried out a land suitability evaluation for surface and drip irrigation in the Shavoor Plain, Iran. The results showed that $41 \%$ of the area was suitable for surface irrigation; $50 \%$ of the area was highly recommended for drip irrigation and the rest of the area was not considered suitable for either 
irrigation method due to soil salinity and drainage problem. Naseri et al. (2009) investigated soil quality for different irrigation methods in Lali plain and considered 6 factors: soil texture, soil depth, lime, soil salinity, drainage, and slope. The results showed that 1732 ha (48.5\%) of studied lands were appropriate for three irrigation methods of surface, drip, and sprinkler, while 384 ha (10.8\%) of the studied lands were not appropriate for surface irrigation and were appropriate for sprinkler and drip irrigations. Albaji et al. (2010) evaluated and compared land suitability for surface, sprinkle, and drip irrigation methods based on the parametric evaluation systems for the Abbas Plain in the Elam Province, Iran. The results obtained showed that sprinkle and drip irrigation systems are more suitable than surface irrigation method for most of the study area. The major limiting factor for both sprinkle and surface irrigation methods was soil texture. However, for drip irrigation method, soil calcium carbonate content and soil texture were restricting factors. Moreover, because of the insufficiency of surface and ground water resources and the aridity and semi aridity of the climate in this area, sprinkle and drip irrigation methods are highly recommended for a sustainable use of this natural resource; hence, the changing of current irrigation methods from gravity surface to pressurized sprinkle and drip in the study area is proposed. Gizachew (2014) evaluated the land suitability for surface and sprinkler irrigation in the Guang watershed, Ethiopia based on FAO guidelines. Geographical Information System (GIS) techniques were used to develop land suitability map. Land characteristics used as criteria for irrigation requirements were soil depth, soil texture, electric conductivity, $\mathrm{pH}$, drainage and slope factors. The results showed that 990.25 ha $(39.61 \%)$ of the Guang watershed were highly suitable (S1) for surface irrigation method. However, 2370 ha $(94.8 \%)$ of the region was unsuitable $(\mathrm{N})$ for sprinkler irrigation method due to soil salinity, drainage and ph. Moreover, this showed that the surface irrigation method was more efficient than the sprinkler irrigation method to intensively and extensively use the land. The resultant map can assist decision makers in ensuring that lands are used according to their suitability. Moreover, GIS technique can provide a powerful tool in agricultural planning of an area for the land use suitability. The technological approach defines GIS as a 
set of tools for the input, storage and retrieval, manipulation, analysis and output of spatial data. This approach however ignores the problem solving aspects of GIS and it has been argued that GIS functionality can play a crucial role in a comprehensive decision-making process. Application of GIS in land use planning was well documented and implemented (Salem et al., 2008). Soil survey data and GIS are important tools in land use planning. Intertwined, they represent an invaluable and underutilized resource. Hazrat et al. (2003) found that the GIS is an important tool that can be used for optimal allocation of water resources of an irrigation project. Mean water balance components results for different months were stored in GIS databases, analyzed and displayed as the monthly crop water requirements maps. A methodology was developed using a Geographic Information System (GIS) to select, design, install and manage an irrigation system for a farm. GIS was used to develop different thematic layers, each consisting of a particular attribute required for analysis of alternative irrigation system types. These layers included data such as: topography, soil texture, soil water retention, bulk density, infiltration rate of water and field drainage system. The GIS facilitated irrigation planning. GIS was found to be a useful tool for a general farm planning analysis. (Holzapfel et al.2012). The main objective of this research was to evaluate land suitability for irrigation methods and crops based on soil mapping by using Geographic Information Systems (GIS).

\section{MATERIALS AND METHODS}

\section{Location:}

Studied area include an area of about 600 feddans at Wadi El-Natron which lies in the north western portion of Egypt. The studied area is located south west of Wadi El Natron. It is bounded by latitudes $3015.0^{\prime \prime}$ and 30 20.0" $\mathrm{N}$ and longitudes 30 10.0" and 30 15.0" E. (map1).

\section{Climate:}

The climate of the area is characterized by extreme aridity long rainless summer and short cold winter with rare rains. The mean monthly maximum temperature ranges from 20.0 to $34.8 \mathrm{C}^{\mathrm{o}}$ while the mean minimum temperature ranges from 7.2 to $20.5 \mathrm{C}^{\circ}$. Rainfall is ranged from 53.7 to $65.8 \mathrm{~mm} /$ year and precipitations is strictly confined to winter season. 


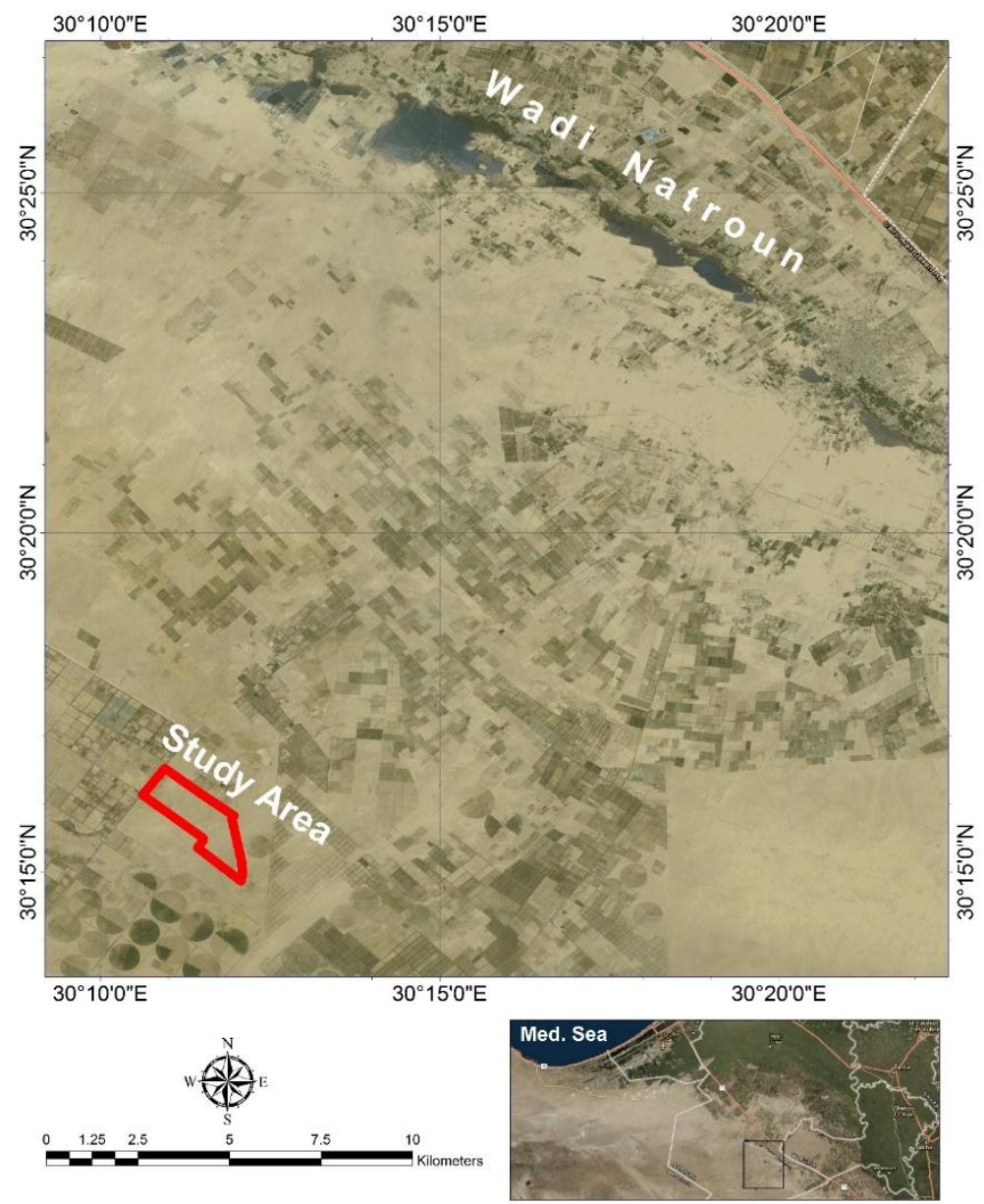

\section{Map (1): Location map of the studied area at Wadi El-Natron}

\section{Geomorphology:}

The land surface of the area is almost flat to slightly undulating and generally sloped towards the Nile Delta.

\section{1- Field work:}

The studied area extends about 638 feddans was surveyed using 454 soil profiles were chosen to represent different point and degraded portions of the studied area (Map 2). Representative profiles were morphologically described according to FAO (2007), and sampled for further laboratory analyses. 


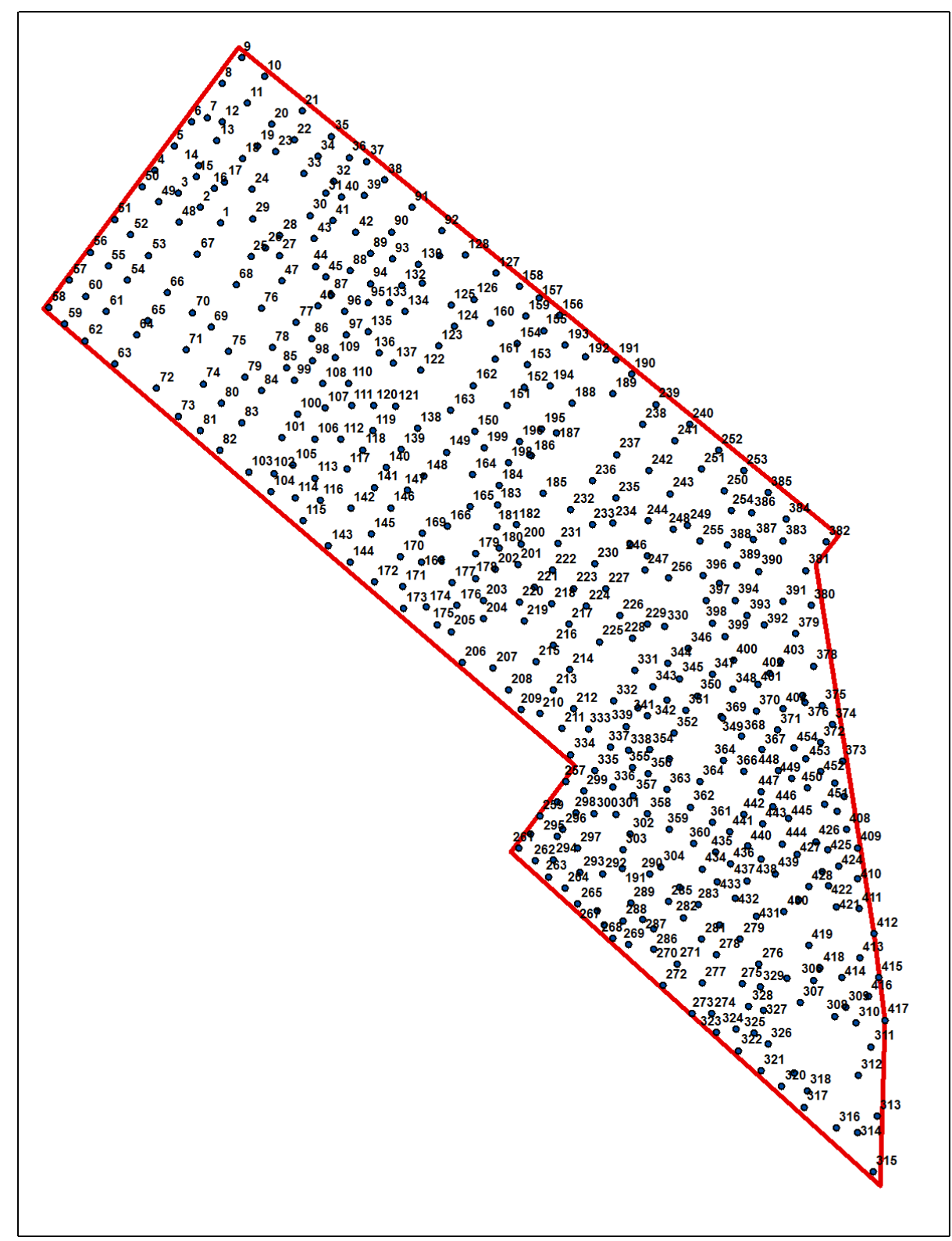

Map 2. Locations of soil profiles in the studied area at Wadi El-Natron

\section{Soil analyses:}

Collected soil samples were analyzed to determine (1) physical properties (Page et al. 1982) soil texture (2) chemical properties such as: electrical conductivity (EC), soluble cations and anions and soil reaction $(\mathrm{pH})$, total calcium carbonate. 


\section{Measuring soil salinity in the field:}

This method is a reasonably accurate way of estimating sodicity, salinity and $\mathrm{pH}$ in most districts. It is most accurate if the soil is dried, ground and weighed out e.g. ( $20 \mathrm{~g}$ soil plus $100 \mathrm{ml}$ water). But the test can also be performed in the field, as set out below. It is most convenient to analyse several soil samples at the same time.

\section{-Equipment:}

Hand held salinity meter (Calibrated). - Clean jar, with sealing lid (400$500 \mathrm{ml}$ is ideal).

Clearly mark the jar at $250 \mathrm{ml}$ and $300 \mathrm{ml}$ level. - Distilled, deionised or rainwater. - Stirring rod.

\section{-Procedure:}

1. Depending on the soil texture and its moisture, the soil may be hard or moist (especially in clay soils) thus making it difficult to break down, if this is the case then use a cheese grater to break the soil down before adding to the distilled water. Alternatively use a stirring rod to crush soil in the distilled water.

2. Add distilled, deionised or rainwater up to the bottom mark $(250 \mathrm{ml})$ of the sample jar. Then add soil, crushed as fine as possible and air dried, until the level reaches the top mark $(300 \mathrm{ml}$, equivalent to approximately $50 \mathrm{~g}$ soil). This equates to a $1: 5 \mathrm{soil} /$ water ratio.

3. Put the lid on and shake the solution vigorously for at least two minutes then allow it to settle for five minutes.

4. Dip the EC meter into the top, clear part of the solution and take a reading (Zhang et al.2005).

\section{GIS processing:}

Radar Sat Images (SRTM) were used as a source of elevation in the study. The ArcGIS Spatial Analyst 10.2.1 extension provides tools for spatial data analysis like (buffering, masking, interpolation.... etc) that apply statistical theory and techniques to the modelling for spatially referenced data.

\section{Land evaluation:}

Land suitability classes for irrigation systems, cultivation and for several field, forage, vegetables and fruit crops were identified for each soil unit according to ( Burt, 1995 ; Sys, 1979 ; Ayers and Westcot, 1985 ; Scianna, 2002) with soil properties and climate conditions. 


\section{RESULTS AND DISCUSSION}

\section{General description of the studied area:}

The studied area has level to nearly level land surface except for some few undulated sites. Elevations ranged gradually between $<80 \mathrm{~m}$ abave sea level (A.S.L) and $>160 \mathrm{~m} \mathrm{A.S.L} \mathrm{with} \mathrm{different} \mathrm{slope} \mathrm{degrees} \mathrm{towards}$ western east direction as shown in map (3). The higher elevation value that recorded $>160 \mathrm{~m}$ A.S.L about $1.8 \%$ for the studeid area, when the lower elevation value that recorded $<80 \mathrm{~m}$ A.S.L about $38.6 \%$ for the studeid area. Morever, the other elevation value that recorded from 80$120 \mathrm{~m}$ A.S.L about $16.2 \%$ and that recorded from 120-160 m A.S.L about $43.4 \%$ of the studied area.

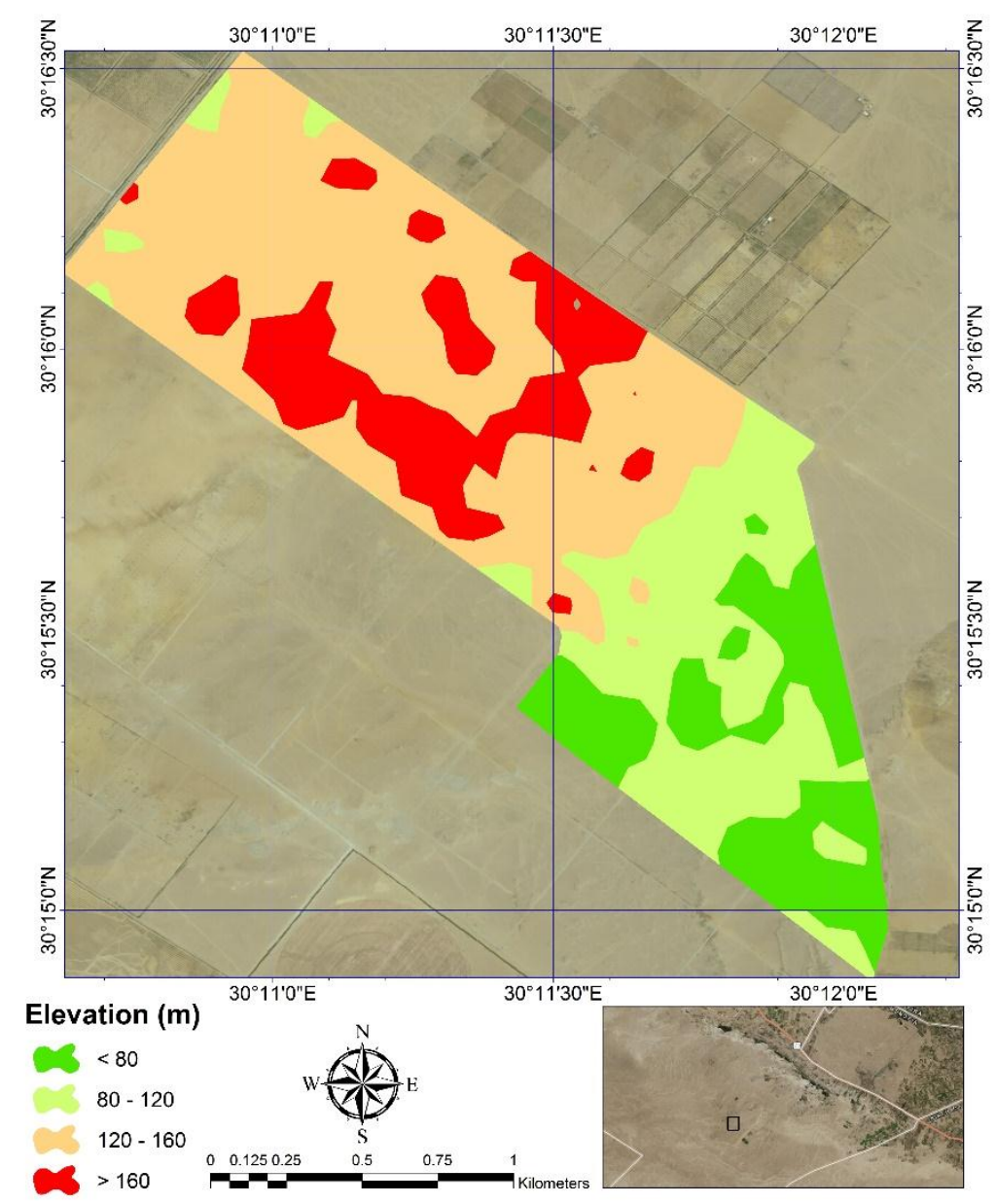

Map (3): Elevation of the studied area at Wadi El-Natron 


\section{Topography}

In general, the topography is a graphical representation of the landscape in the area and quantitatively expressed in units of slope (grade, length, and shape). Slopes are generally calculated in percent $(\%)$ or degrees $\left({ }^{\circ}\right)$. Classification of slope, in the studied area refers to (Burt, 1995). The slope analysis in Map (4) found that studied area is dominated by the slope of the class (4-15\%) it is an area of $71.88 \%$. The remaining $28.12 \%$ is the slope class $(0-3 \%)$. View of the slope criteria for settlements into two slope classes, the studied area that represented $71.88 \%$ and slope (4$15 \%)$ were more suitable for sprinkler and drip irrigation systems, when the studied area that represented $28.12 \%$ and slope (0-3\%) were more suitable for surface irrigation system.

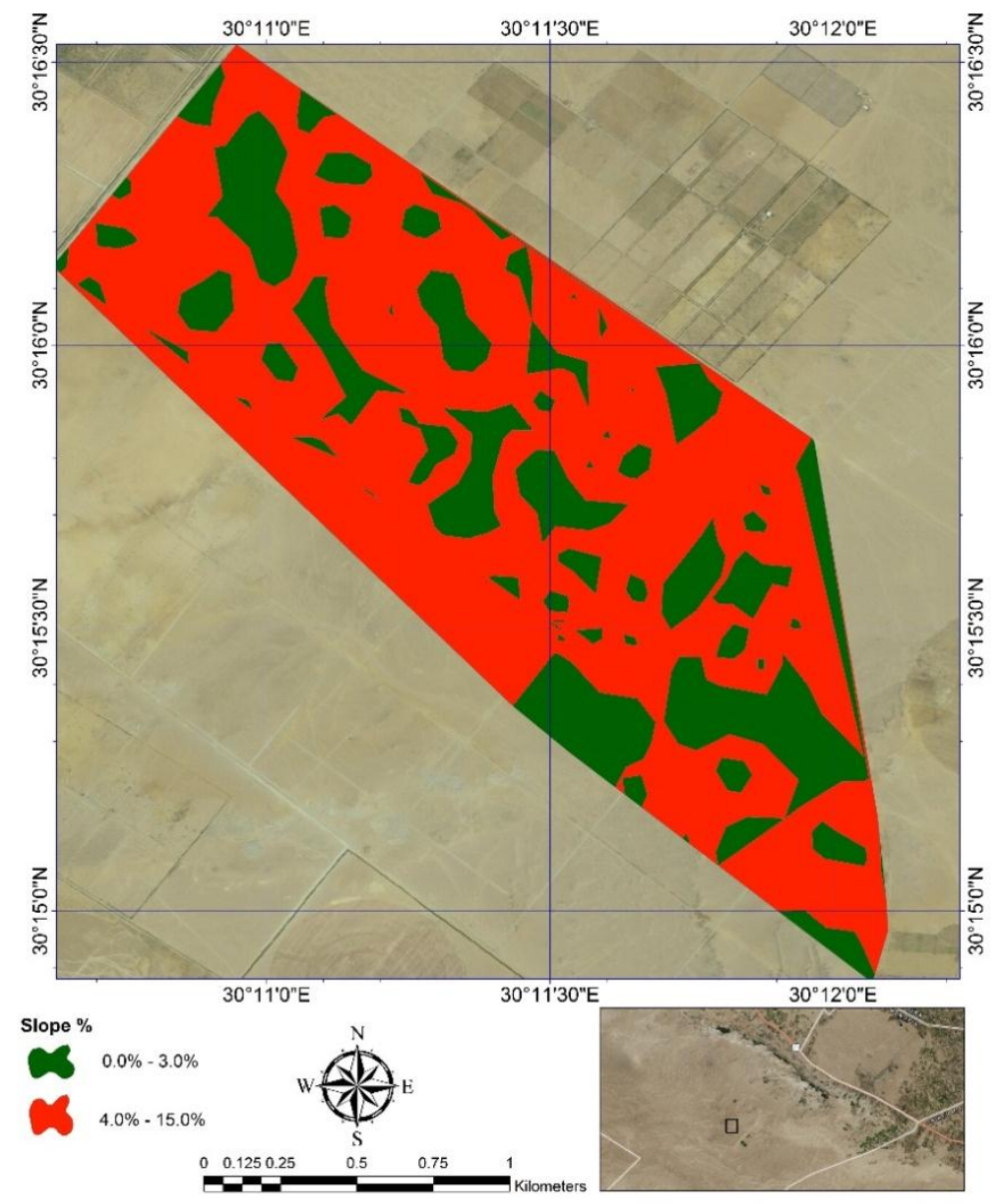

Map (4): Slope of the studied area at Wadi El-Natron 


\section{Electric conductivity (EC)}

As shown in Map (5), most of the studied area soils are non-saline to slightly saline where electric conductivity (EC) varied between 0.90 and 4 $\mathrm{dS} / \mathrm{m}$, while some studied profiles were salt affected and have saline EC values ranged between $(8-16 \mathrm{dS} / \mathrm{m})$ and $>16$ $\mathrm{dS} / \mathrm{m}$, where the most dominant soluble salts were sodium chloride according to (Scianna, 2002) . Additionally, the EC valuse ranged from (0-2 dS/m), (2-4 dS/m), (4-8 dS/m), (8-16 dS/m), and (> $16 \mathrm{dS} / \mathrm{m})$ represent $69.84 \%, 16.15 \%, 8.78 \%, 4.85 \%$ and $0.38 \%$ of the studied area respectively. In general, if the soil salinity in the surface soil (seeding area) is greater than $4 \mathrm{ds} / \mathrm{m}$, it may inhibit or delay germination and early seedling growth.

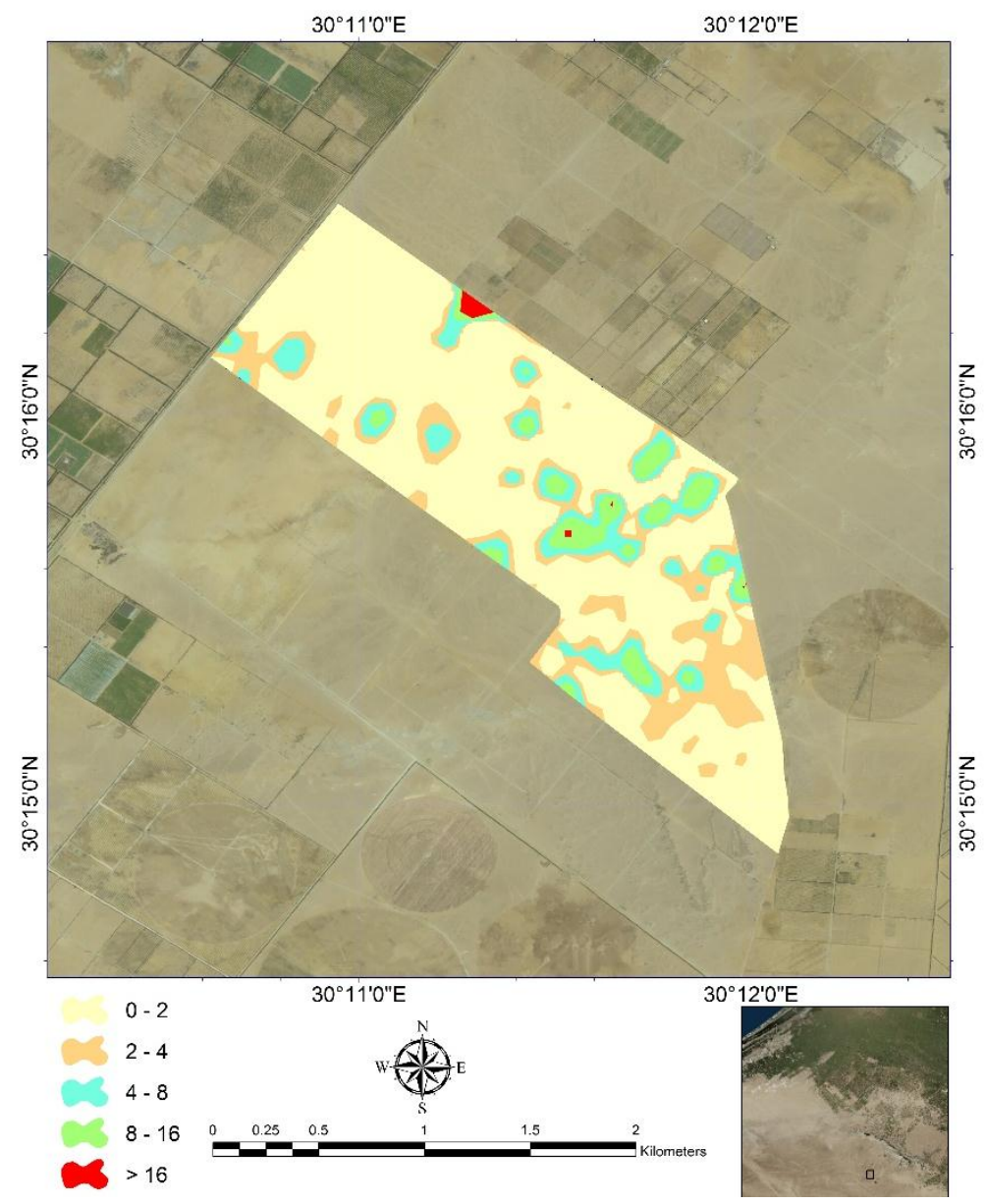

Map (5): Electric conductivity (EC) of the studied area at Wadi El-Natron 
This slowed germination may then delay emergence, allowing soil crusting and disease problems to reduce the crop stand. Moreover, it is clear that the salinity ranging from $(0-2 \mathrm{dS} / \mathrm{m}),(2-4 \mathrm{dS} / \mathrm{m})$, and (4-8 $\mathrm{dS} / \mathrm{m}$ ) were suitable for most of all crops and does not affect the productivity of most crops, while the salinity ranging from $(8-16 \mathrm{dS} / \mathrm{m})$ and $(>16 \mathrm{dS} / \mathrm{m})$ will lead to reduced crop yields for more than $50 \%$ (Ayers and Westcot, 1985).

\section{Soil reaction $(\mathbf{p H})$}

Soil reaction values were neutral with relatively alkaline tendency, where $\mathrm{pH}$ ranged from7.3 to 8.4 for the whole area (97.4\% of the studied area). Most of the studied area was non alkaline except for some limited sites ranged from 8.5 to $>9$ (2.25\% of the studied area), while $0.35 \%$ of the studied area were acid that ranged from $<3.5$ to 6.5 (Map 6). This results according to (Scianna, 2002).

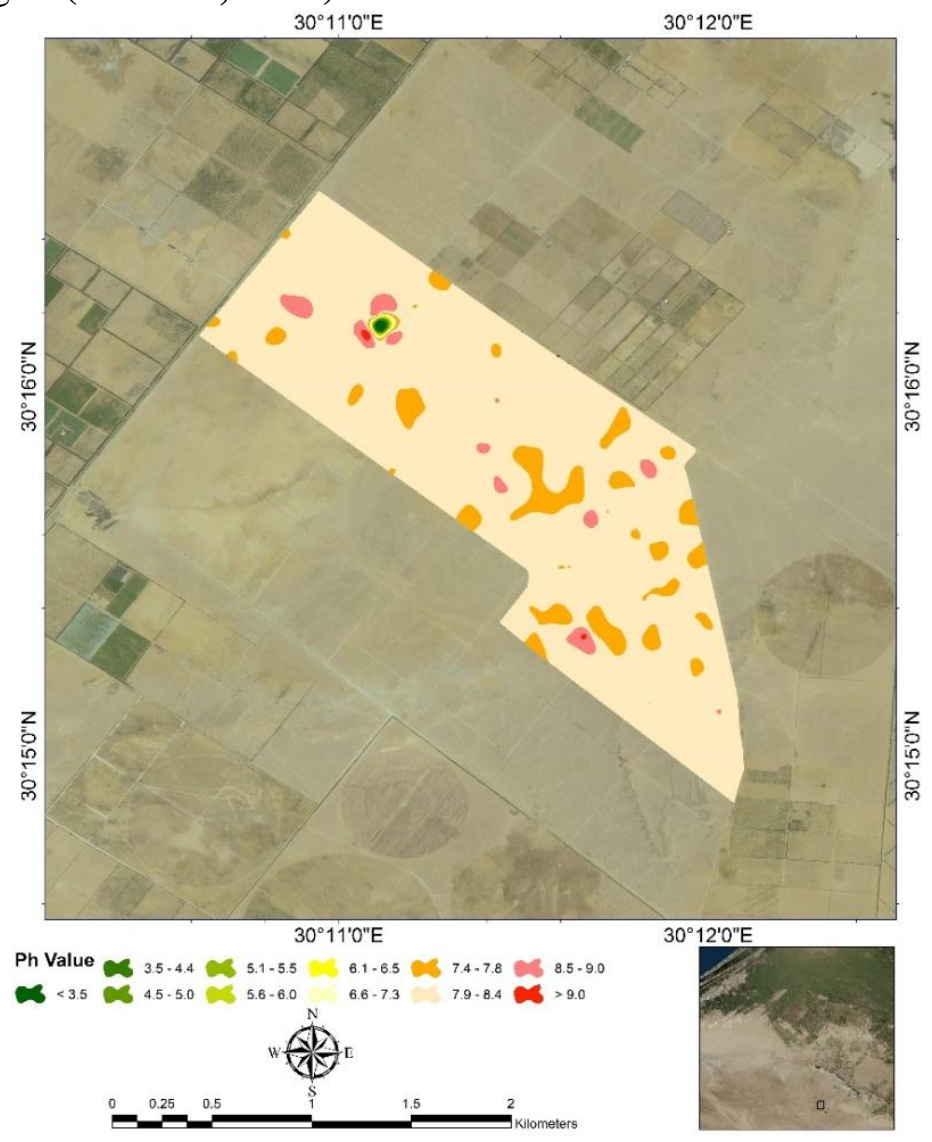

Map (6): Soil reaction (pH) of the studied area at Wadi El-Natron 
In arid regions like Egypt, limited rainfall results in minimal leaching of bases and salts under non-irrigated conditions, so soluble salts of $\mathrm{Ca}, \mathrm{Mg}$, and $\mathrm{Na}$ remain in high concentrations in the soil. As shown in map (7) the sodium adsorption ratio (SAR) exceeds 16 and varied in a wide range from $<0.5$ to $>16$.

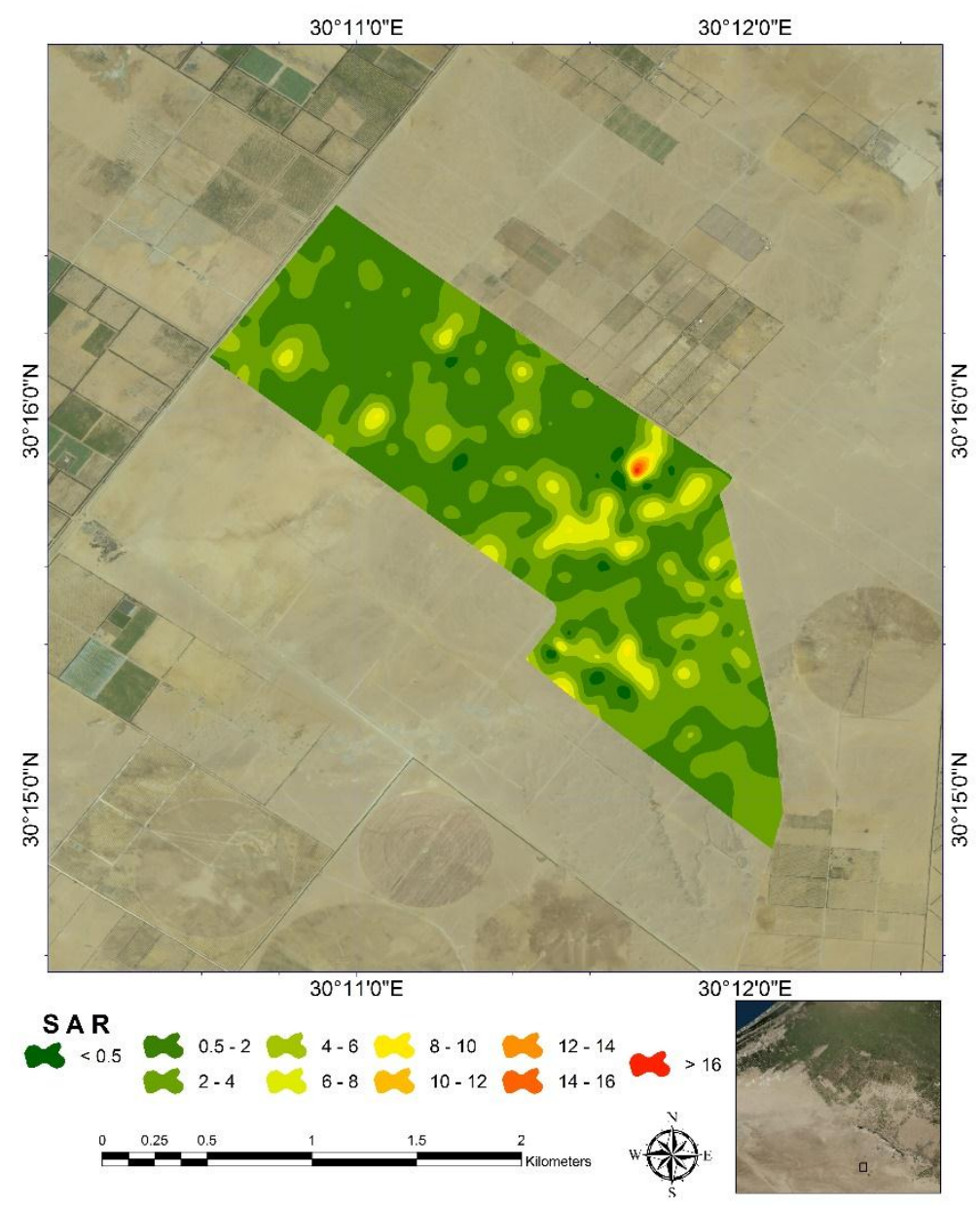

Map (7): Sodium adsorption ratio (SAR) of the studied area at Wadi El-Natron

Most of the studied area (99.86\%) were (SAR) less than 12 and $0.14 \%$ of the studied area were (SAR) between 14 and more than 16. This means that, most of the studied area especially that had EC about less than 4 $\mathrm{ds} / \mathrm{m}$ and SAR less than 12 represented normal soil and suitable for most crops ( $86 \%$ of the studied area), On the other side, the EC more than 4 
$\mathrm{ds} / \mathrm{m}$. and SAR below or above 13 represented saline soil and unsuitable for most of crops (14\% of the studied area) (Horneck et al., 2007: Scianna, 2002). Granted, sodium adsorption ratio (SAR) describes the ratio of $\mathrm{Na}$ relative to $\mathrm{Ca}$ and $\mathrm{Mg}$ - two cations that moderate the adverse effects of $\mathrm{Na}$. The greater the SAR, the more $\mathrm{Na}$ relative to $\mathrm{Ca}$ and $\mathrm{Mg}$, the greater the toxicity to plants. According to maps 8, 9, and 10 for distribution of $(\mathrm{Na}),(\mathrm{Ca})$, and $(\mathrm{Mg})$ in the studied area. It can be noted that, the Read and Orange color that represented the high levels of $\mathrm{Na}$ (800-1000 ppm) and more than $1000(\mathrm{ppm})$ and about $0.8 \%$ of the studied area were highly in (SAR). Conversely, the dark Green and Green that represented the low levels of $\mathrm{Na}(<20 \mathrm{ppm})$ and $(20-200 \mathrm{ppm})$ and about $79.73 \%$ of the studied area were decreased in (SAR).

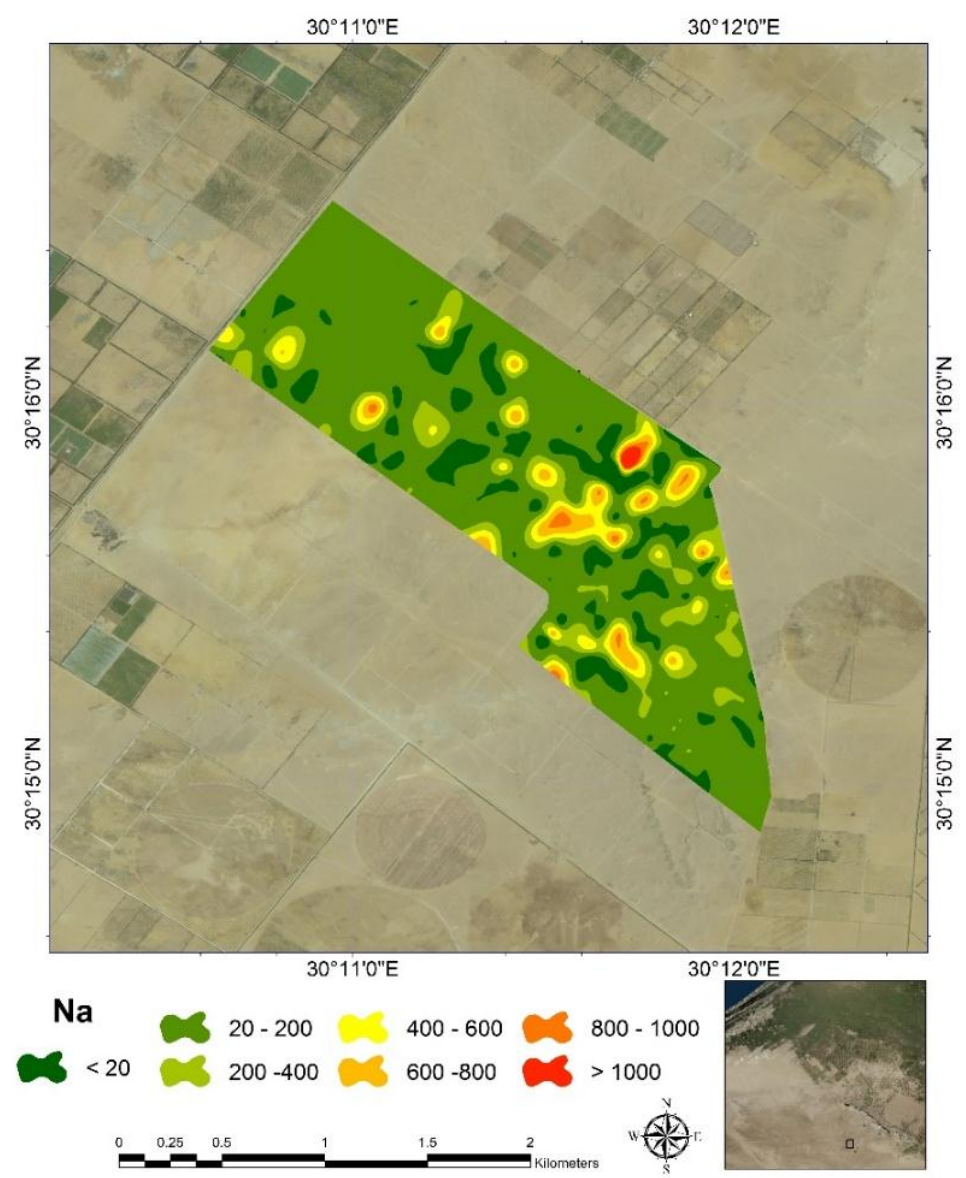

Map (8): Sodium distribution (Na) of the studied area at Wadi El-Natron 


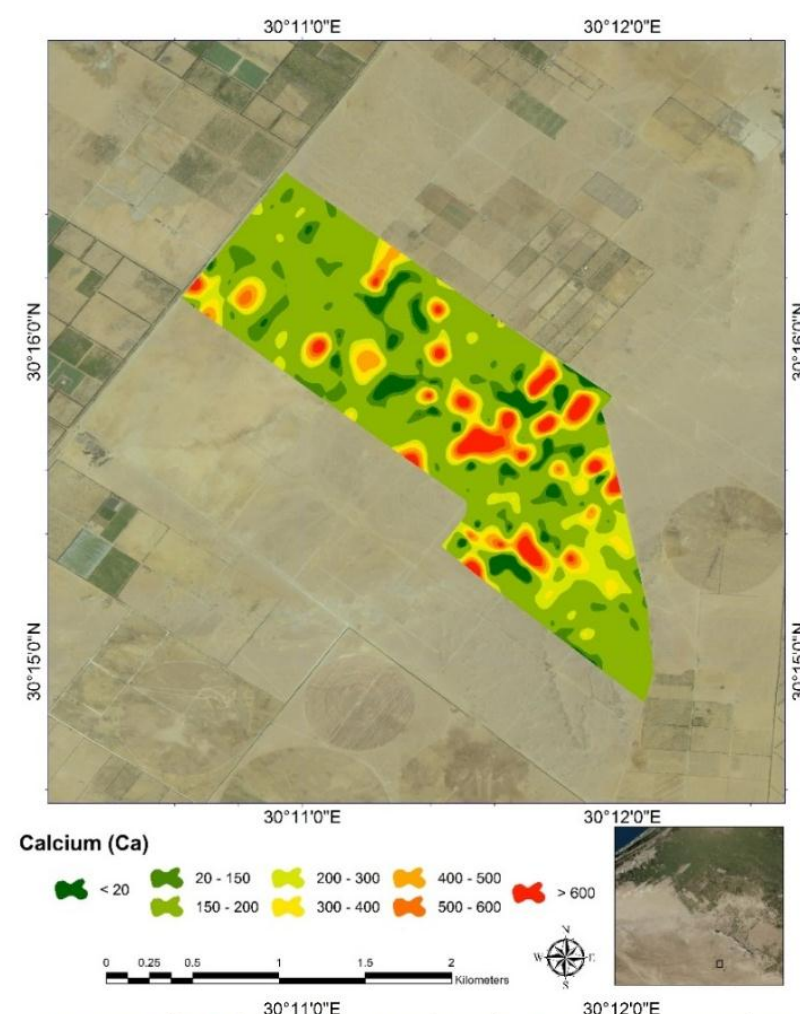

Map (9): Calcium distribution (Ca) of the studied area at Wadi El-Natron

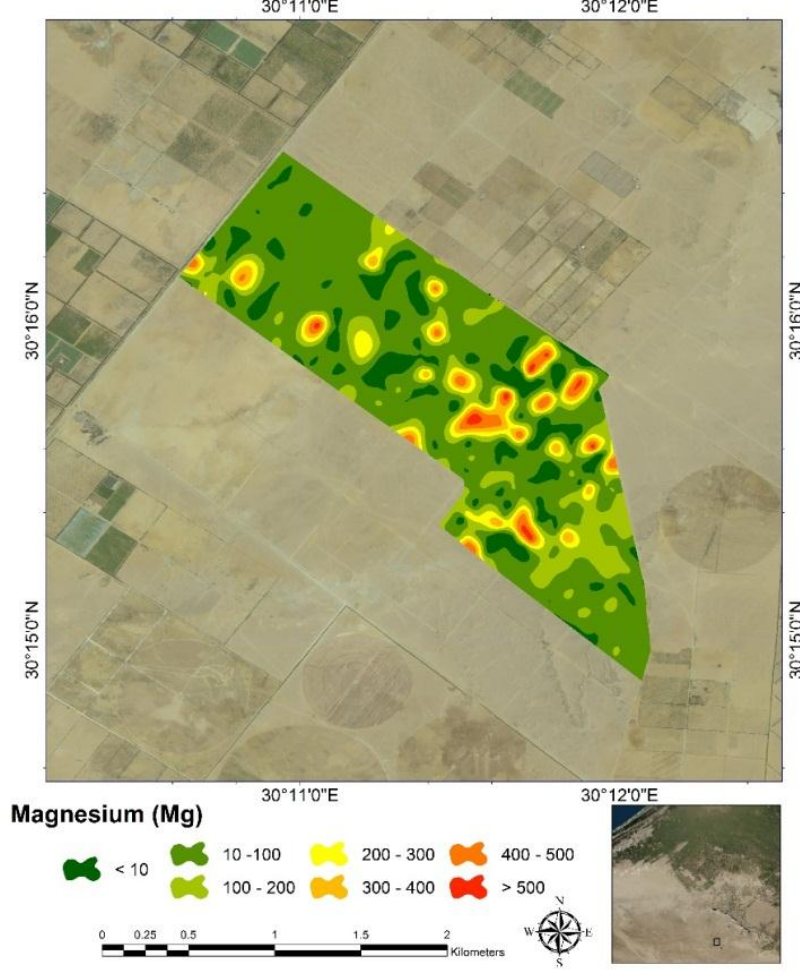

Map (10): Magnesium distribution (Ca) of the studied area at Wadi El-Natron 


\section{CONCLUSIONS}

The results show that the GIS maps based on soil properties, most of the studied area were suitable for cultivation and few of the studied area were unsuitable for cultivation according to EC and (SAR), limiting in suitable area for surface irrigation system and increasing of suitable area for sprinkler and drip irrigation systems according to slope. Also, most of the studied area were alkaline soil, few of the studied area were neutral soil and acid soil according to ph. Additionally, On the other hand, because of the insufficiency of water in arid and semiarid climate, the optimization of water use efficiency is necessary to produce more crops per drop and to help resolve water shortage problems in the agricultural sector. The shift from surface irrigation to modern irrigation systems, e.g., sprinkler and drip irrigation systems, therefore, offers significant water-saving potentials. Moreover, the main limiting factors in using different irrigation systems in this area were (soil texture, $\mathrm{CaCo} 3$ and slope) and electrical conductivity (EC) for crops. Finally, the using GIS maps reliable to be a good indicator for detecting the suitable irrigation systems and crops for this area of study.

\section{REFERENCES}

Albaji, M., Landi, A., Boroomand Nasab, S., and Moravej, K. (2008). "Land suitability evaluation for surface and drip irrigation in Shavoor plain Iran.” J. Appl. Sci., 84, 654-659

Albaji M., Boroomand Nasab S., Naseri A.A., and Jafari S. (2010). Comparison of different irrigation methods based on the parametric evaluation approach in Abbas plain-Iran. Journal of Irrigation and Drainage Engineering. (ASCE) Volume 136, Issue 2: pp.131-136.

Ayers, R. S. and D. W. Westcot (1985). Water Quality for Agriculture. FAO Irrigation and Drainage Paper No. 29 (Rev. 1), Food and Agriculture organization of the United Nations, Rome, Italy.

Barberis, A., and Minelli, S. (2005). "Land evaluation in the Shouyang County, Shanxi Province, China.” Proc., 25th Course Professional Master, IAO, Italy, http://www.iao.florence.it/training/geomatics/ Shouyang/China_25hq.pdf 
Burt, C.M. (1995). Guidelines for Establishing Irrigation Scheduling Policies. Theme V: Interaction Between Water Delivery and Irrigation Scheduling. ICID/FAO Workshop on Irrigation Scheduling: From Theory to Practice. Rome, Italy. September 1213.

Dengize, O. (2006). "A comparison of different irrigation methods based on the parametric evaluation approach." Turk. J. Agric. For., 30, 21- 29.

De la Rosa D (2000) MicroLEIS 2000: Conceptual Framework, Instituto de Recursos Naturalesy Agrobiologia, CSIC, Avda. Reina Mercedes 10, 41010 Sevilla, Spain.

FAO (2007) Planning for sustainable use of land resources: towards a new approach, W. G. Sombroek and D. sims. Land and Water Bulletin 2, FAO, Rome

Gizachew, A. (2014) Land Suitability Evaluation for surface and sprinkler irrigation Using Geographical Information System (GIS) in Guang Watershed, Highlands of Ethiopia. Journal of Environment and Earth Science. Vol.4, No.22: 140-149.

Hazrat, A. M.; Teang Shui, L. and Walker, W.R. (2003). Optimal water management for reservoir based irrigation projects using Geographic Information System. Journal of Irrigation and Drainage Engineering of ASCE, v.129, p.1-10.

Holzapfel, E. A.; Mariño, M. A. and Chavez-Morales, J. (1985). Procedure to select an optimum irrigation method. Journal of Irrigation and Drainage Engineering of ASCE, v.111, p.319-329.

Holzapfel, E.A.; Arumi, J. L.; Rodríguez, A. and da Silva Paz, V. P. (2012) Geographic information system supported farm irrigation system design and planning. Water Resources and Irrigation Management, v.1, n.1, p.7-14.

Horneck, D.S., Ellsworth, J.W., Hopkins, B.G., Sullivan, D.M., and Stevens, R.G., (2007). Managing Salt-Affected Soils for Crop Production. PNW 601-E. Oregon State University, University of Idaho, Washington State University. 
Jackson, M.L., (1973) Soil chemical analysis. Advanced course Ed.2. A Manual of methods useful for instruction and research in soil chemistry, physical chemistry of soil, soil fertility and soil genesis. Revised from Original Edition (1955).

Khalifa, M.E.A (2009). Assessment of soil limiting factors effect on land productivity at Wadi El-Faregh area, West of Delta, Egypt. ALEXANDRIA SCIENCE EXCHANGE JOURNAL, VOL. 30, No. 2 APRIL-JUNE

Lee, T.M., Yeh, H.C., (2009). Applying remote sensing techniques to monitor shifting wetland vegetation: a case study of Danshui River estuary mangrove communities, Taiwan. Ecological Engineering 35, 487-496.

Liu, W., Qin, Y., and Vital, L. (2006). "Land evaluation in Danling County, Sichuan Province, China.” Proc.,26th Course Professional Master: Geometric and Natural Resources Evaluation, IAO, Italy,

Martin, D., Saha, S.K., (2009). Land evaluation by integrating remote sensing and GIS for cropping system analysis in a watershed. Current Science 96, 1.

Mbodj, C., Mahjoub, I., and Sghaiev, N. (2004). "Land evaluation in the Oud Rmel Catchment, Tunisia." Proc., 24th Course Professional Master: Geometric and Natural Resources Evaluation, IAO, Italy, http://www.iao.florence.it/training/geomatics/Zaghouan/Tunisia_ 24lq.pdf(Apr. 22, 2007).

Naseri A.A, Rezania R, and Albaji M (2009). Investigation of soil quality for different irrigation systems in Lali Plain, Iran. Journal of Food, Agriculture \& Environment. 7(3\&4): 955-960.

Page, A. L., Miller, R. H. and Keeny, D. R. (1982) Methods of Soil Analysis, Part 2- Chemical and Microbiological Properties. Agronomy Monograph No. 9. ASA, SSSA, Madison, WI.

Pan, G., Pan, J., (2012). Research in crop land suitability analysis based on GIS. Computer and Computing Technologies in Agriculture 365, 314-325

Salem, M. Z., Ageeb, G. W. and Rahim, I. S. (2008). Land suitability for agricultural of certain crops in Albostan area, Egypt. Research J of Agriculture and Biological Sci. 4: 485-499. 
Scianna, J. (2002). HortNote No.5, Salt- affected soils: Their causes, measure, and classification. https://www.nrcs.usda.gov/Internet/FSE.../stelprdb1044788.pdf

Singha, C. and Swain, K.C. (2016). Land suitability evaluation criteria for agricultural crop selection: A review. Agricultural Reviews, 37 (2) 2016: 125-132.

Sonneveld, M.P.W., Hack-ten Broeke, M.J.D., van Diepen, C.A., and Boogaard, H.L., (2010). Thirty years of systematic land evaluation in the Netherlands. Geoderma 156, 84-92.

Stockle, C.O., (2007). Environmental Impact of Irrigation: A Review water research Washington state University. Washington

Sys, C. (1979) Evaluation of the physical environment for irrigation in terms of land characteristics and land qualities. World Soil Resources Report No.50: 60-76, FAO, Rome.

Sys, C.; Van Ramst, E.; and Debaveye, J. (1991) Land evaluation. Part I Principle in land evaluation and crop production calculation. Agricultural publication - no.7, General administration for development cooperation, Brussels, Belgium.

Zhang, H., LJ.L. Schroder; J.J. Pittman, J.J. Wang, and M.E. Payton. (2005). Soil salinity using saturated paste and 1;1 soil and water extracts. Soil Sci. Soc. Am. J. 69:1146-1151.

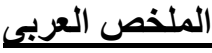

تحديد نظم الرى والمحاصيل المناسبة باستخدام تطبيق نظم المعلومات الجغرافية

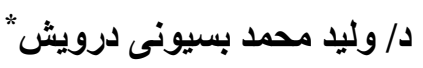

الهذف الرئيسى لهذا العمل هو تحديد نظم الرى والمحاصيل المناسبة من خلال الاعتماد

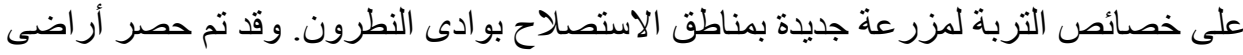

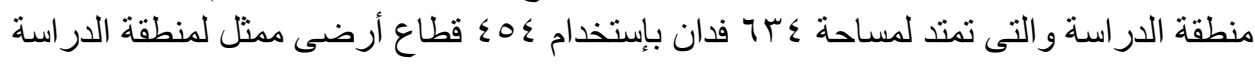
و المشاكل السائدة بها. وخصائص التربة لمنطقة الدر اسة تتمثل في العمق (طبقات قطاع التهاع التربة)،

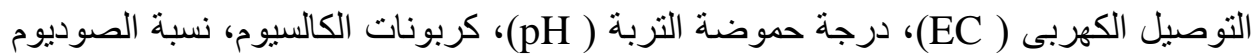

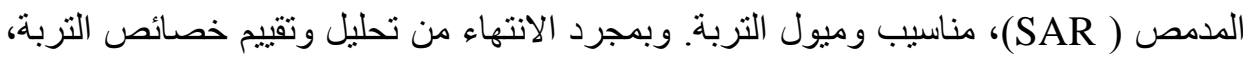
تم عمل مجموعة من الخرائط المناسبة لمنطقة الدراسة باستخدام تطبيق نظم الثناء من المطلومات

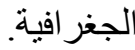

*مدرس الهندسة الزراعية ـ معهل الدراسات و البحوث البيئية ـ جامعة مدينة السادات * 
- منطقة الدراسة غير ملحية إلى متوسطة الملوحة (EC يتر اوح بين 1 إلى أكبر من 17

. $(\mathrm{ds} / \mathrm{m}$

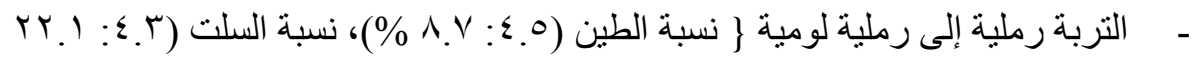

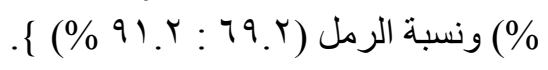

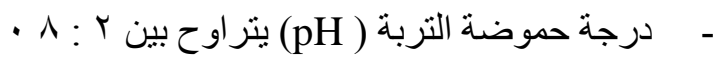

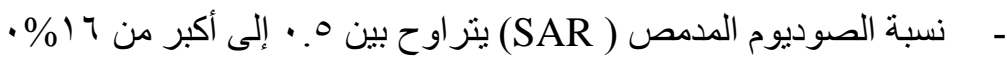

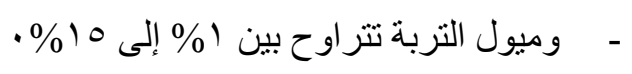

و يتضح من النتائج السابقة أن:

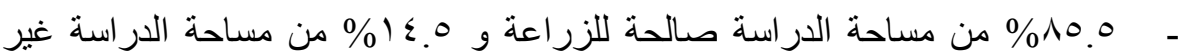

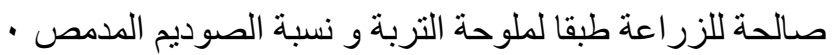

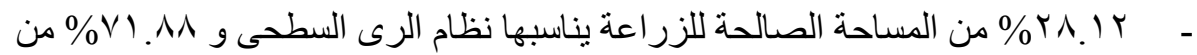

المساحة الصالحة للزراعة بناسبها نظامى الرى بالرش والرئام الرى بالتنقيط طبقا لميول

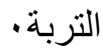

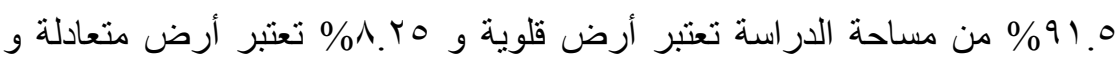

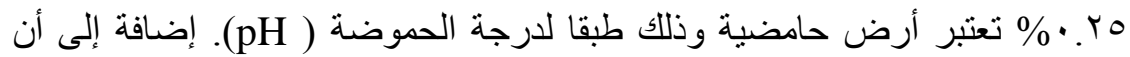

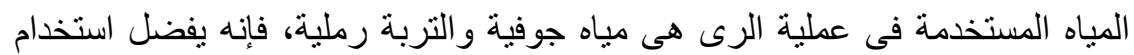

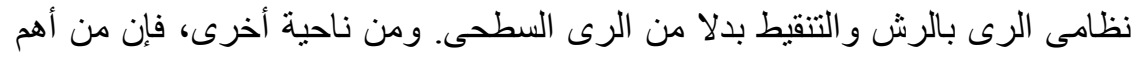

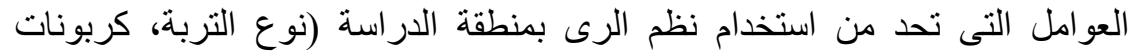

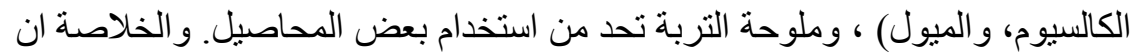

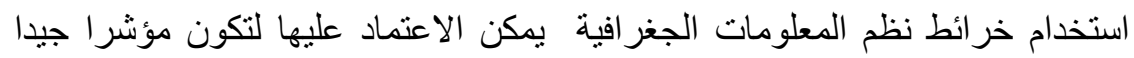

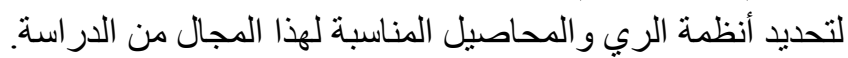

